
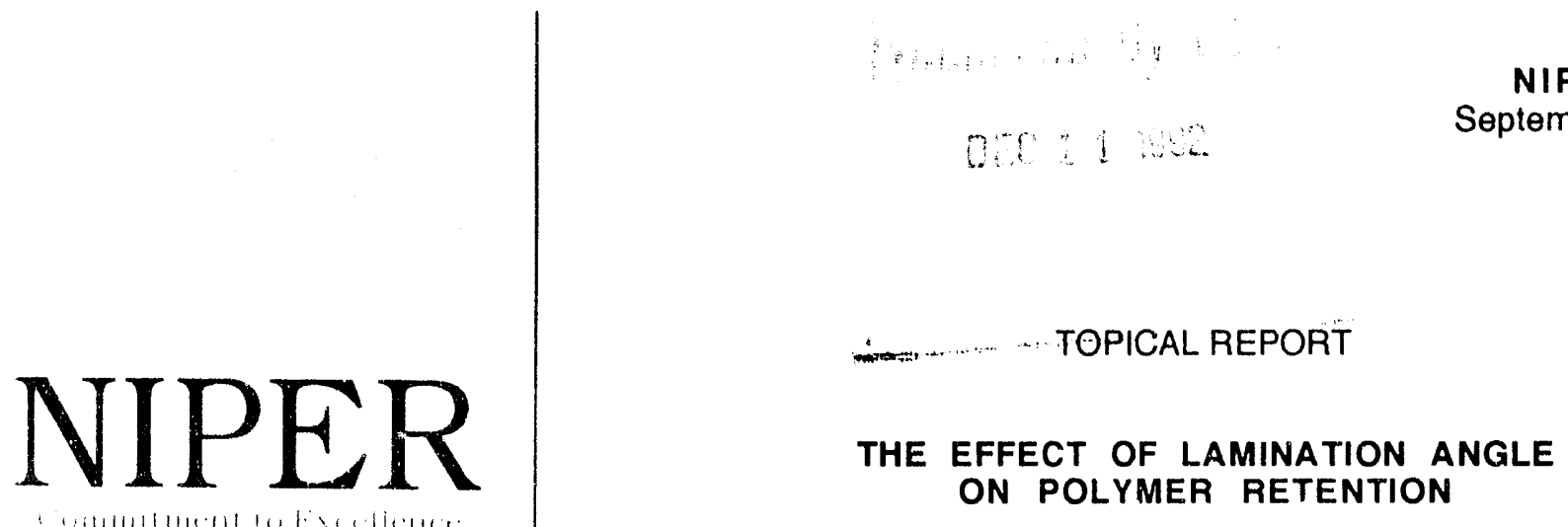

By Hong W. Gao

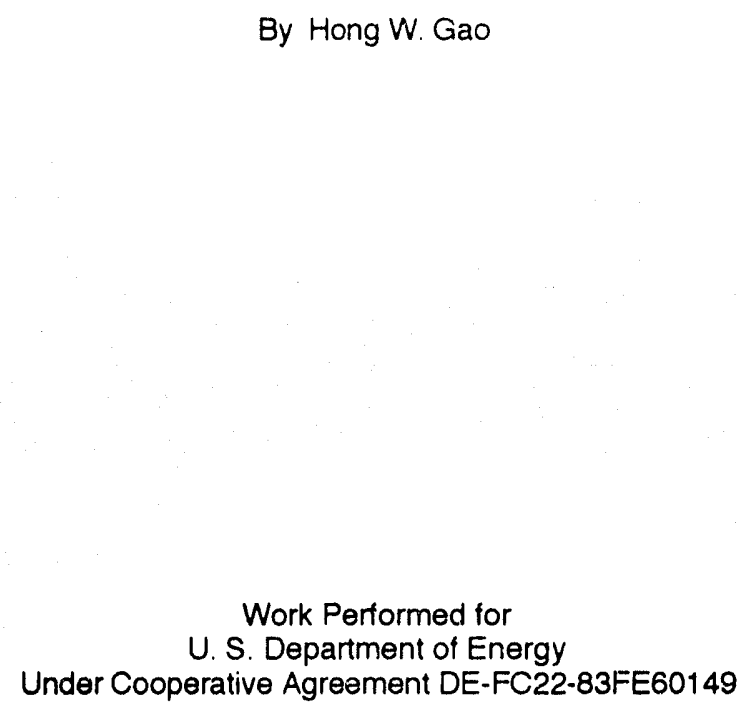

National Institute for Petroleum and Energy Research

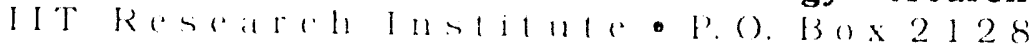
Bartlestille. (1klahema 7.4005-2128 - (918) 336-2.400 
I NIPER--630

DE93 004304

TOPICAL REPORT

\title{
THE EFFECT OF LAMINATION ANGLE ON POLYMER RETENTION
}

Project BE4C, Milestone 5, FY92 Annual Research Plan

\author{
By \\ Hong W. Gao \\ Work Performed for the \\ U.S. Department of Energy \\ Under Cooperative Agreement DE-FC22-83FE60149 \\ Jerry Casteel, Project Manager \\ Bartlesville Project Office \\ U.S. Department of Energy
}

\section{DISCLAIMER}

This report was prepared as an account of work sponsored by an agency of the United States Government. Neither the United States Government nor any agency thereof. nor any of their employees, makes any warranty, express or implied, or assumes any legal liability or responsibility for the accuracy, completeness, or usefulness of any information, apparatus, product, or process disclosed, or represents that its use would not infringe privately owned rights. Reference herein to any specific commercial product, process, or service by trade name, trademark, manufacturer, or otherwise. does not necessarily constitute or imply its endorsement. recommendation, or favoring by the United States Government or any agency thereof. The views and opinions of authors expressed herein do not necessarily state or reflect those of the United States Government or any agency thereof.

IIT Research Institute National Institute for Petroleum and Energy Research

Box 2128

Bartlesville, Oklahoma 74005

$918336-2400$ 


\section{TABLE OF CONTENTS}

ABSTRACT
INTRODUCTION
ACKNOWLEDGMENTS
EXPERIMENTAL
Core Materials
Polymer Solution
CT Tracer Tests
Coreflood Procedure
RESULTS AND DISCUSSION
COrefloods
CT Tracer TestS
REFCLUSIONS

1. Properties of core samples

Tables

2. Test conditions in corefloods

\section{Illustrations}

1. CT derived porosity distributions of Berea cores A, B, and C.............................. 8

2. Correlation between measured porosity and permeability for Berea sandstone .......9

3. Normalized effluent concentration profiles for biopolymer from core A ……........ 9

4. Normalized effluent concentration profiles for biopolymer from core B ................ 10

5. Normalized effluent concentration profiles for biopolymer from core C................ 10

6. Retention of biopolymer in cores $\mathrm{A}, \mathrm{B}$, and $\mathrm{C}$ during and after the first slug of polymer injection ................................................................................ 11

7. Retention of biopolymer in cores $\mathrm{A}, \mathrm{B}$, and $\mathrm{C}$ during and after the second slug of polymer injection ...................................................................................... 11

8. CT images of tagged brine tracer slug (light color) in Berea core A saturated with untagged brine ...................................................................................... 12

9. CT images of tagged brine tracer slug (light color) in Berea core B saturated with untagged brine ..................................................................................... 13

10. CT images of tagged brine tracer slug (light color) in Berea core $\mathrm{C}$ saturated with untagged brine 


\title{
THE EFFECT OF LAMINATION ANGLE ON POLYMER RETENTION \\ By Hong W. Gao
}

\begin{abstract}
Polymer retention may be affected by the reservoir geological structure due to lamination of the mineral surfaces. These laminae are very prevalent in Class I reservoirs. To account for the effect of lamination angle on polymer retention, several corefloods with three fired, rectangular, Berea sandstone cores were conducted. The three cores were cut at three different angles, 0,30 , and 90 degrees, with respect to the direction of laminations. A multiple slug retention method was used to determine the retention of a biopolymer in each core. Tracer tests were conducted before and after the biopolymer flow to determine how the retained biopolymer affected the fluid advance. A computed tomography (CT) scanning mechod was used to monitor the advance of the tracer. All corefloods and tracer tests were conducted at low flow rates similar to that in reservoirs.

Coreflood tests revealed that polymer retention, which was mainly caused by mechanical entrapment, was higher in cores that had laminations parallel to the direction of flow than in cores that had crossbed laminae. In cores that had crossbed laminae, polymer retention increased with an increase in the lamination angle. Retained polymer is harmful to the stability of fluid front in cores that have laminations parallel to the direction of flow, but is helpful in cores that $i$. ve crossbed laminae.
\end{abstract}

This work was performed in project BE4C for the Department of Energy and represents completion of milestone 5 of the FY92 Annual Research Plan under Cooperative Agreement DE-FC22-83FE60149.

\section{INTRODUCTION}

The success of any surfactant/polymer enhanced oil recovery (EOR) method depends not only on the effectiveness of chemicals to mobilize residual crude oil but also on the ability of the polymer solution to maintain effective mobility control throughout the reservoir. If mobility control is ineffective or lost, a less-than-anticipated oil recovery is inevitable. Polymer retention is one of the factors that are responsible for lost mobility control. The main mechanisms of polymer retention are adıorption, mechanical entrapment, or deep-bed filtration and hydrodynamic retention. ${ }^{1}$ Dynamic coreflood experiments with native cores at reservoir flow rates are usually required to estimate polymer loss due to retention. For a particular reservoir, the parameters 
considered in coreflood experiments usually include the type of polymer, polymer concentration, flow rate, and permeability. None have considered the effect of geological structure on polymer retention. A review of several chemical rlood field projects in Class I reservoirs, ${ }^{2-5}$ the most recent one being the Loudon (IL) project, ${ }^{5}$ revealed that polymer propagation was impeded, resulting in poor mobility control and poor recovery efficiency. Polymer retention from field tests was found to be much higher than that from the coreflood values. It was conceived that polymer molecules were retained due to entrapment, most probably caused by the intercalation or shale layers that are known to be present in a fluvial deltaic depositional environment. ${ }^{2}$ In this work, the effect of lamination angle on polymer retention was investigated.

\section{ACKNOWLEDGMENTS}

This work was sponsored by the U.S. Department of Energy under Cooperative Agreement DE-FC22-83FE60149. The author wishes to thank the following NIPER employees: Dr. M. K. Tham for his helpful suggestions, Dr. L. Tomutsa and S. Jackson for their technical discussions, and A. Brinkmeyer for his assistance in obtaining the CT images; and R. Hauge, summer intern; and H. C. Li, Institute of Geological Science of Shengli Petroleum Administration, for their help in obtaining the viscosity data.

\section{EXPERIMENTAL}

\section{Core Materials}

Three fired, rectangular, Berea sandstone cores (A, B, C) cut at three different angles with respect to the direction of laminations were used in this work. Core $\mathrm{A}$ was cut along the direction of laminations. Cores B and $\mathrm{C}$ were cut at 30 and 90 degrees, respectively, from the direction of laminations. All cores were cut from the same Berea sandstone block from Cleveland Quarry, Ohio. Firing was conducted in an oven at $1,000^{\circ} \mathrm{F}$ for 24 hours. Table 1 shows the dimensions, average permeability, and porosity of each core. The locations and directions of the laminations and areas of porosity contrast were determined using a computed tomography (CT) scanning method. During the CT scan, each core was scanned every $8 \mathrm{~mm}$ along the longest axis. Core C was also scanned every $2 \mathrm{~mm}$ along the longest axis for the first $5 \mathrm{~cm}$. Figure 1 shows the CT determined distributions of porosity for cores A, B, and C, respectively. Both cores B and C show the presence of crossbed laminae. As shown in Fig. 1, scans using $2 \mathrm{~mm}$ for each cross section scanned (C-1) revealed more laminations than those using $8 \mathrm{~mm}$ apart. Using a petrographic image analysis (PIA) technique 6 and Carman-Kozeny equation, ${ }^{7}$ calculated permeability as a function of measured porosity for the Berea core is shown in Fig. 2. This figure indicates that low-porosity laminations had low permeability. As shown in Table 1, the porosity 
determined from the CT method was fairly close to that from a brine saturation method.

\section{Polymer Solution}

The polymer solution used in the coreflood was prepared from Pfizer's FLOCON $4800 \mathrm{C}$ and filtered through a $1.2-\mu \mathrm{m}$ millipore paper at $10 \mathrm{psig}$. The concentration of the biopolymer used was $1,000 \mathrm{ppm}$, and the salinity was $53 \mathrm{meq} / \mathrm{L} \mathrm{NaCl}(3,100 \mathrm{ppm})$. The low salinity used was to minimize the adsorption effect. Both biopolymer solution and brine contained $500 \mathrm{ppm}$ of $37.3 \%$ formaldehyde as a biocide.

\section{CT Tracer Tests}

Before conducting tracer and coreflood tests, each core was coated with epoxy, and its brine permeability was measured. Tracer tests were conducted at a low flow rate, $1.39 \mathrm{ft} / \mathrm{d}(0.424$ $\mathrm{m} /$ day), before and after the polymer flow to determine how polymer retention affected the fluid front advancement and the shape of the tracer slug. These tests were conducted by injecting a brine slug tagged with $10 \%$ sodium iodide into the core saturated with untagged brine. During tracer tests, the flow behavior of the tagged brine was monitored throughout its advance through the core by both conventional $\mathrm{CT}$ and topogram scanning. CT density is calculated and reported in Houndsfield units (HU).

\section{Coreflood Procedure}

In corefloods, a multiple slug retention method was used to determine the retention of a biopolymer in each core. A first slug of the biopolymer solution was injected into the core followed by more than $8 \mathrm{PV}$ of brine $(53 \mathrm{meq} / \mathrm{L} \mathrm{NaCl})$. The effluents were collected with a fractional collector and analyzed for the amount of biopolymer produced. The effluent biopolymer concentration was determined by viscosity measurements at a shear rate of $20.4 \mathrm{sec}^{-1}$ using a Contraves Low Shear 30 viscometer. Using a simple material balance technique, the amount of polymer retained was calculated. This procedure was repeated for a second slug of polymer injection. Table 2 shows actual pore volumes of biopolymer solution and brine injected intu each core. The flow rates used in cores A, B, and C were $5.47(1.35 \mathrm{ft} / \mathrm{d}), 5(1.41 \mathrm{ft} / \mathrm{d})$, and $4.3 \mathrm{~mL} / \mathrm{hr}$ $(1.11 \mathrm{ft} / \mathrm{d})$, respectively. These flow rates corresponded to an apparent shear rate of about $10 \mathrm{sec}^{-1}$ in each core. All corefloods were conducted at room temperature $\left(22.4^{\circ} \mathrm{C}\right)$

\section{RESULTS AND DISCUSSION}

\section{Corefloods}

Coreflood results with the three cores are shown in Figs. 3 through 5 for cores A, B, and C, 
respectively. In each figure, normalized effluent biopolymer concentration was plotted as a function of pore volumes (PV) injected. The area under each curve is the amount of biopolymer produced. As shown in each figure, the effluent biopolymer concentration never reached that of the injected biopolymer solution, indicating that equilibrium retention had not been reached under the experimental conditions. The maximum effluent biopolymer concentration from core A was smaller than that from core $\mathrm{B}$ or $\mathrm{C}$, indicating that polymer retention was highest in core $\mathrm{A}$. Since initial polymer concentration had not been reached, data from the corefloods were replotted in terms of cumulative polymer retention as a function of pore volumes injected and compared with each other. Figure 6 shows the cumulative polymer retention in the three cores as a function of pore volumes injected during and after the first siug of polymer injection. Figure 7 shows the same kind of plot during and after the second slug of polymer injection. As shown in each figure, during the polymer injection, core $\mathrm{A}$, which had laminations parallel to the flow direction, gave the highest polymer retention, and Core $\mathrm{B}$, which had a lamination angle of 30 degrees wi.h respect to the direction of the longest axis, gave the lowest polymer retention. The maximum amounts of polymer retention in cores $\mathrm{A}, \mathrm{B}$, and $\mathrm{C}$ were $1,007,816$, and $916 \mathrm{~kg} /($ acre-m), respectively, during the first slug of polymer injection, and were 894,768 , and $859 \mathrm{~kg} /($ acre-m) during the second slug of polymer injection.

During the post brine flood, most of the retained polymer was flushed out of the core, leaving only polymer with irreversible retention inside the core. As shown in figs. 6 and 7 , core $A$, which gave the highest polymer retention during polymer flow, also gave the highest irreversible retention and core $\mathrm{B}$, which gave the lowest polymer retention during polymer flow, also gave the lowest irreversible retention. The amounts of irreversible retention from the first slug of polymer injection in cores $\mathrm{A}, \mathrm{B}$, and $\mathrm{C}$ were 309,73 , and $201 \mathrm{~kg} /($ acre-m), respectively. From the second slug of polymer injection, the amounts of irreversible retention were 188, 15, and 138 $\mathrm{kg} /($ acre- $\mathrm{m})$, respectively. Total amounts of irreversible retention from these two slugs of polymer injection in cores $\mathrm{A}, \mathrm{B}$, and $\mathrm{C}$ were 497,88 , and $339 \mathrm{~kg} /($ acre-m), respectively. These results indicated that polymer retention was higher in cores, such as core $A$, that had laminations parallel to the direction of flow than in cores, such as cores B and $C$, that had crossbed laminations. Possible explanation for this was that in parallel core $A$, some of the polymer that was retained in the low-permeability laminations was by-passed by the injected fluid since the injection fluid did not have to flow across the low-permeability laminations in order to flow through the core. Conversely, in cores $\mathrm{B}$ and $\mathrm{C}$, the injection fluid had to flow across the low-permeability laminations. As a consequence, some of the polymer that was retained in the low-permeability laminations was flushed out. In cores with crossbed laminations, polymer retention increased with an increase in the lamination angle. Because of low salt concentration and clean core materials used, adsorption was negligible under experimental conditions. X-ray diffraction analysis showed 
that Berea sandstone contained only trace amounts of kaolinite; therefore, most of the polymer retained can be attributed to mechanical entrapment.

\section{CT Tracer Tests}

Figures 8 through 10 show the CT images of the tracer slug advancing through the cores during tracer tests conducted before and after the polymer flow. In core A (Fig. 8), fingers were seen both before and after the polymer flow. However, after the polymer flow, fingering became more severe. This was caused by an increased permeability contrast between various rock layers after the polymer flow. The increased permeability contrast was caused by the retained polymer that decreased the permeability in the low-permeability laminations to a larger degree than in the high-permeability layers. Therefore, in cores that had laminations parallel to the direction of flow, retained polymer had an adverse effect on the stability of the fluid front.

In core B (Fig. 9), the tracer front became more piston-like after the polymer flow than before the polymer flow. Before polymer flow, gravity effect caused the fluid front to deviate from the direction of laminations. After polymer flow, the front became more uniform, indicating that gravity effect was overcome by the retained polymer in the low-permeability laminations. Similar effect of retained polymer on the shape of tracer front was also seen in core C (Fig. 10). In Fig. 10, the slug size of tracer used after the polymer flow was about $65 \%$ larger than that used before the polymer flow. Therefore, in cores that have crossbed laminations, retained polymer is helpful in improving the stability of the fluid front.

\section{CONCLUSIONS}

Based on the results of this study, the following conclusions can be drawn:

1. During and after polymer flow, polymer retention that is mainly caused by mechanical entrapment is higher in cores that have laminations parallel to the direction of flow than in cores with crossbed laminae.

2. In cores that have crossbed laminae, polymer retention increases with an increase in the lamination angle.

3. Retained polymer has an adverse effect on the stability of the fluid front in cores that have laminations parallel to the direction of flow.

4. In cores that have crossbed laminae, retained polymer is beneficial to the stability of the fluid front. 


\section{REFERENCES}

1. Gao, H. W. Mobility Control in Oil Recovery by Chemical Flooding. State-cf-the-Art Review. DOE Report NIPER-146, January, 1987, 95 pp. NTIS Order No. DE87001210

2. U.S. Deparument of Energy. Opportunities to Improve Oil Productivity in Unstructured Deltaic Reservoirs. Technical Summary and Proceedings of the Technical Symposium, Dallas, Texas, January 29-30, 1991. DOE Report DOE/BC-91/6/SP, 1991. NTIS order No. DE91002237.

3 EOR Field Case Histories. SPE Reprint Series No. 23. 1987 Edition. Society of Petroleum Engineers, Richardson, TX.

4. Taggart, Davis L., and George C. Russell. Micellar/Polymer Flood Post Test Evaluation Well. Pres. at the 1981 SPE/DOE Second Joint Symposium on Enhanced Oil Recovery, Tulsa Okla., Apr. 5-8, 1931. SPE/DOE paper 9781.

5. Hul, C., L. H. Landis, N. K. Maer Jr., P. H. McKinnery, and N. A. Dougherty. Simulation to Support Interpretation of the Loudon Surfactant Pilot Tests. Pres. at the 65th Annual Technical Conference of the Society of Petroleum Engineers, New Orleans, LA, Sept. 23-26, 1990. SPE paper 20465.

6. Tomutsa, Liviu, A. Brinkmeyer, and C. Raible. Determining Petrophysical Properties of Reservoir Rocks by Image Anclysis. DOE Report NIPER-378, March, 1989, 27 pp. NTIS Order No. DE89000734

7. Carman, P. C. Trans., Inst. Chem. Eng., London, v. 15, 1937, p. 150. 
Table 1. Properties of core samples.

\begin{tabular}{|c|c|c|c|c|c|}
\hline $\begin{array}{c}\text { Core } \\
\text { sample }\end{array}$ & $\begin{array}{c}\text { Lamination } \\
\text { angle, degree }\end{array}$ & Dimensions & $\begin{array}{c}\text { Porosity, \% } \\
\text { CT method }\end{array}$ & $\begin{array}{c}\text { Porosity, \% } \\
\text { Vol. method }\end{array}$ & $\begin{array}{c}\text { Brine } \\
\text { permeability, mD }\end{array}$ \\
\hline $\mathrm{A}$ & 0 & $4.00 \times 4.06 \times 24.37 \mathrm{~cm}$ & 19.6 & 20.08 & 258 \\
\hline $\mathrm{B}$ & 30 & $3.81 \times 3.81 \times 24.13 \mathrm{~cm}$ & 19.3 & 19.32 & 267 \\
\hline $\mathrm{C}$ & 90 & $4.02 \times 3.84 \times 24.33 \mathrm{~cm}$ & 19.7 & - & 180 \\
\hline
\end{tabular}

Table 2. - Test conditions in corefloods.

\begin{tabular}{|c|c|c|c|c|c|}
\hline $\begin{array}{c}\text { Run } \\
\text { No. }\end{array}$ & $\begin{array}{c}\text { Core } \\
\text { sample }\end{array}$ & $\begin{array}{c}\text { Slug size of polymer } \\
\text { solution, PV }\end{array}$ & $\begin{array}{c}\text { Slug size of chase } \\
\text { brine, } \mathrm{PV}\end{array}$ & $\begin{array}{c}\text { Injection rate, } \\
\mathrm{mL} / \mathrm{hr}(\mathrm{ft} / \mathrm{d})\end{array}$ & $\begin{array}{c}\text { Apparent shear rate } \\
\text { in core, } \mathrm{sec}^{-1}\end{array}$ \\
\hline 1 & A & 3.51 & 8.03 & $5.5(1.35)$ & 10.0 \\
\hline 2 & A & 4.49 & 8.18 & $5.5(1.35)$ & 10.0 \\
\hline 3 & B & 3.66 & 10.170 & $5.0(1.41)$ & 10.2 \\
\hline 4 & B & 5.19 & 8.90 & $5.0(1.41)$ & 10.2 \\
\hline 5 & C & 3.50 & 8.23 & $4.3(1.11)$ & 9.9 \\
\hline 6 & C & 4.54 & 8.10 & $4.3(1.11)$ & 9.9 \\
\hline
\end{tabular}


A
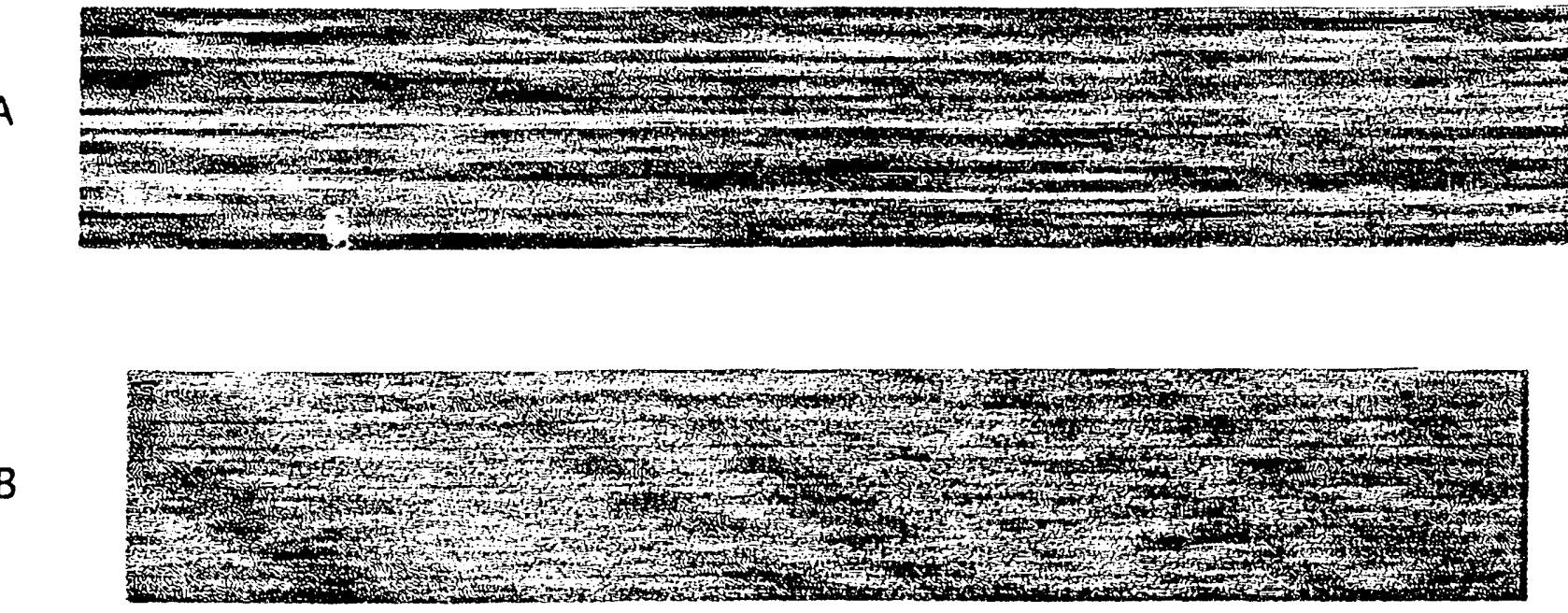

C
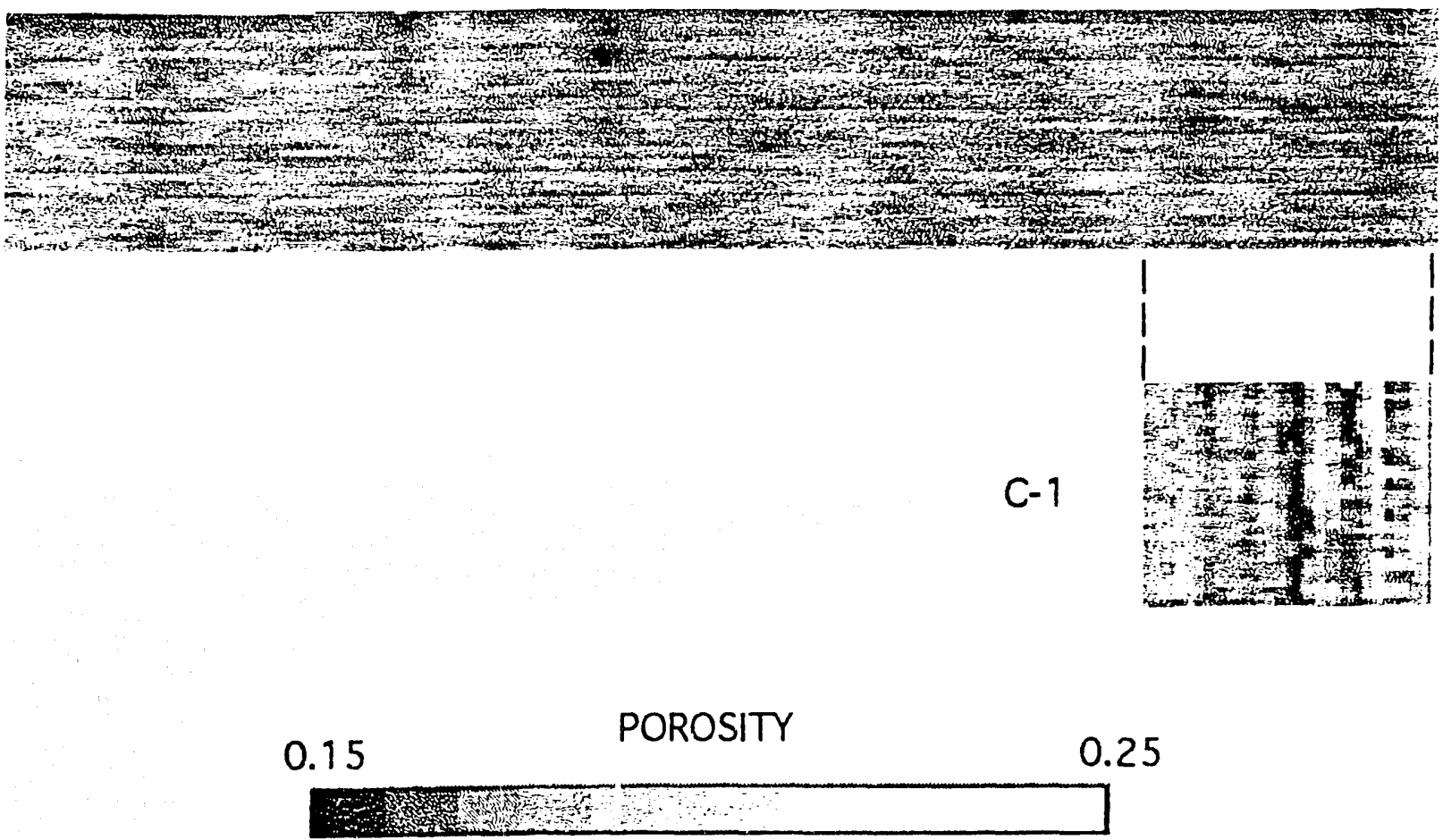

Figure 1. - CT derived porosity distributions of Berea cores A, B, and C. 


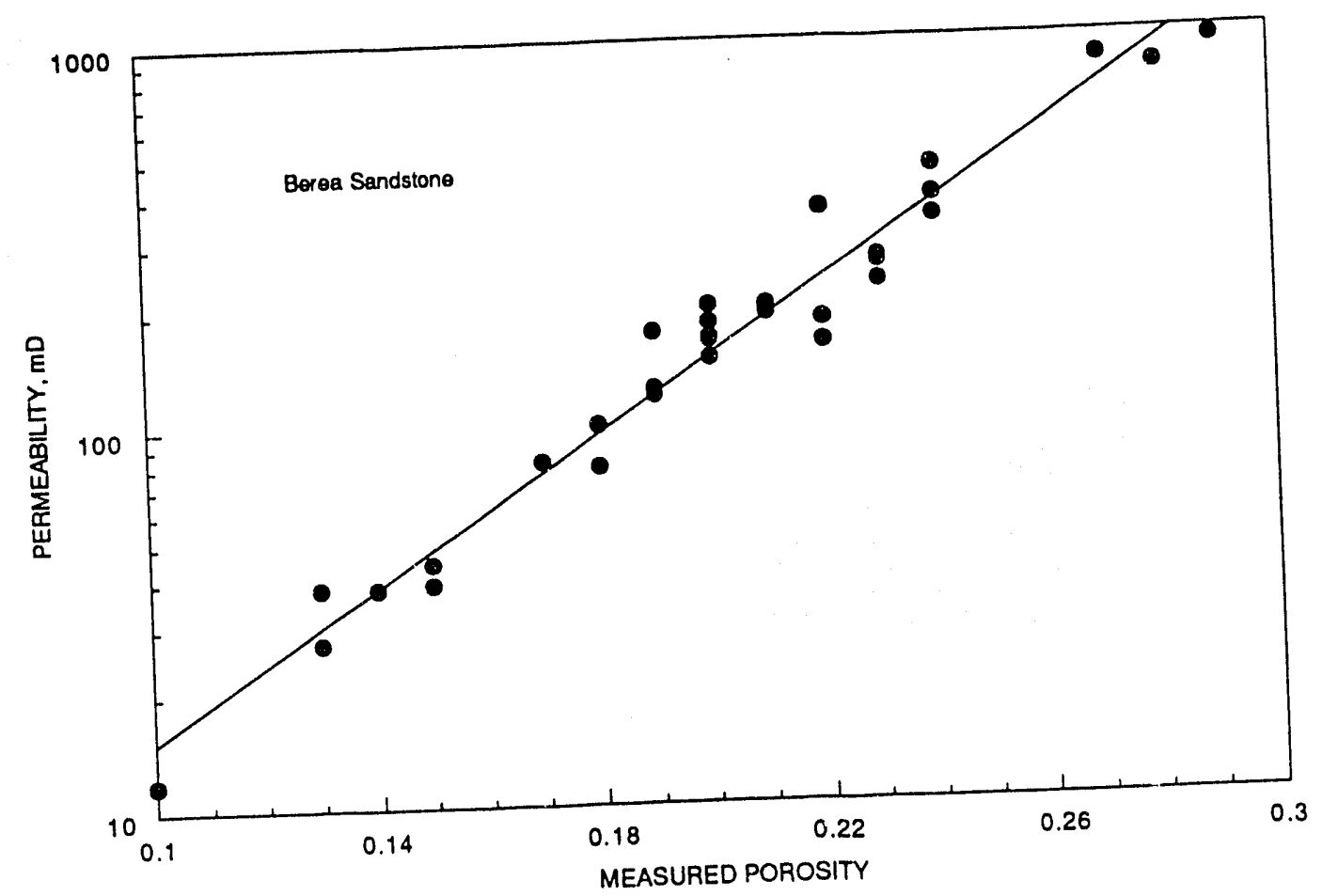

Figure 2. - Correlation between measured porosity and permeability for Berea sandstone.

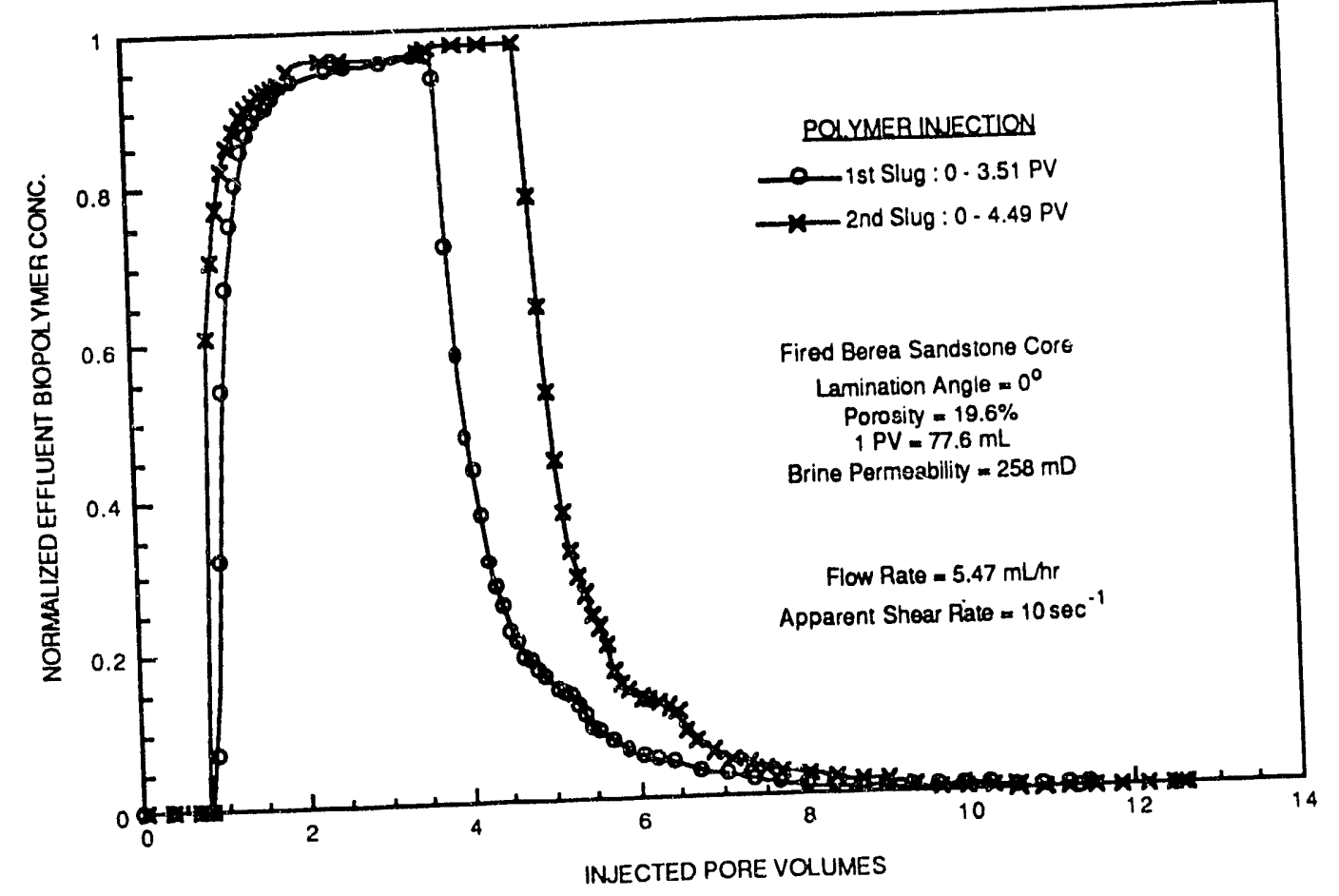

Figure 3. - Normalized effluent concentration profiles for biopolymer from core A. 


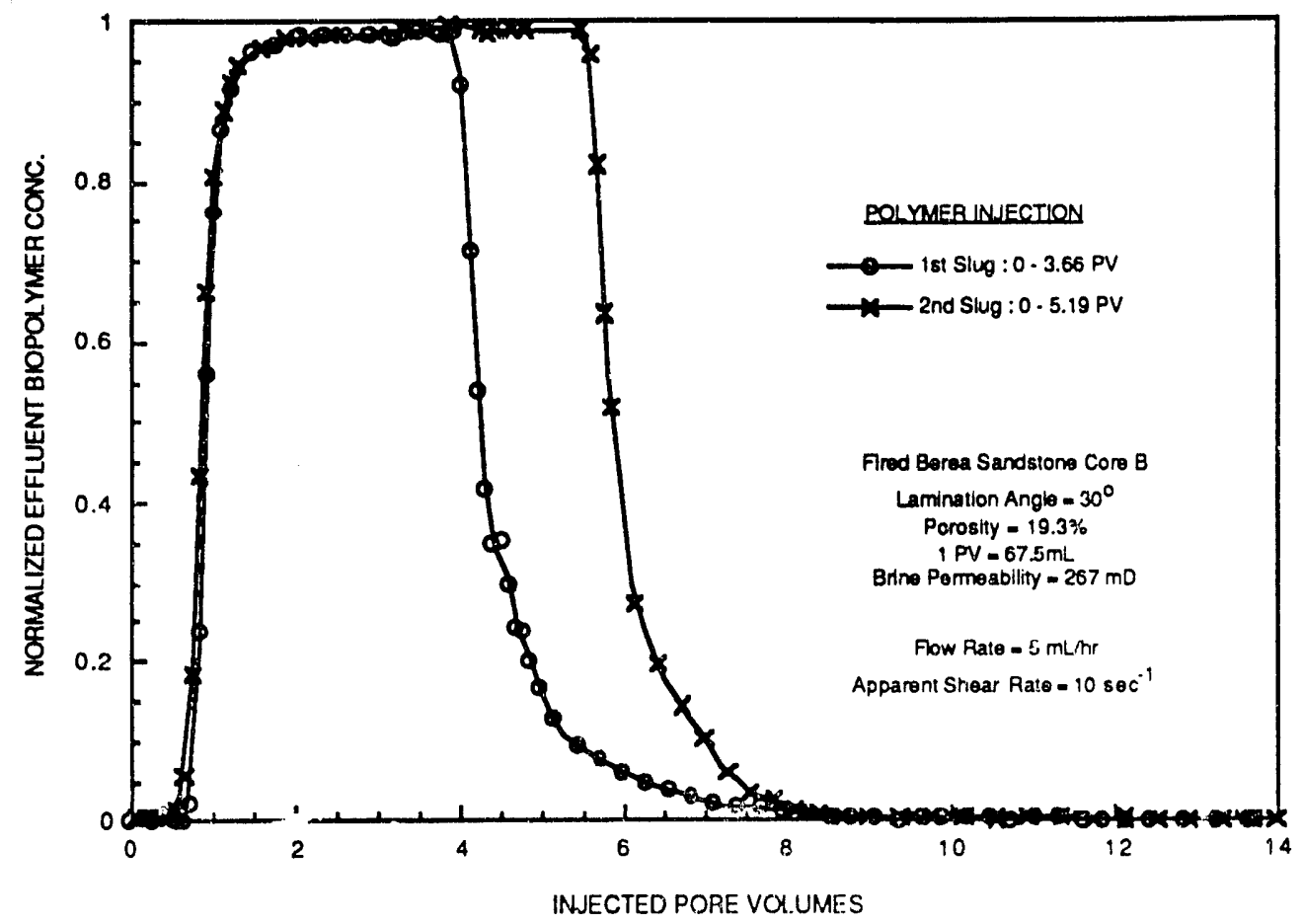

Figure 4. - Normalized effluent concentration profiles for biopolymer from core B.

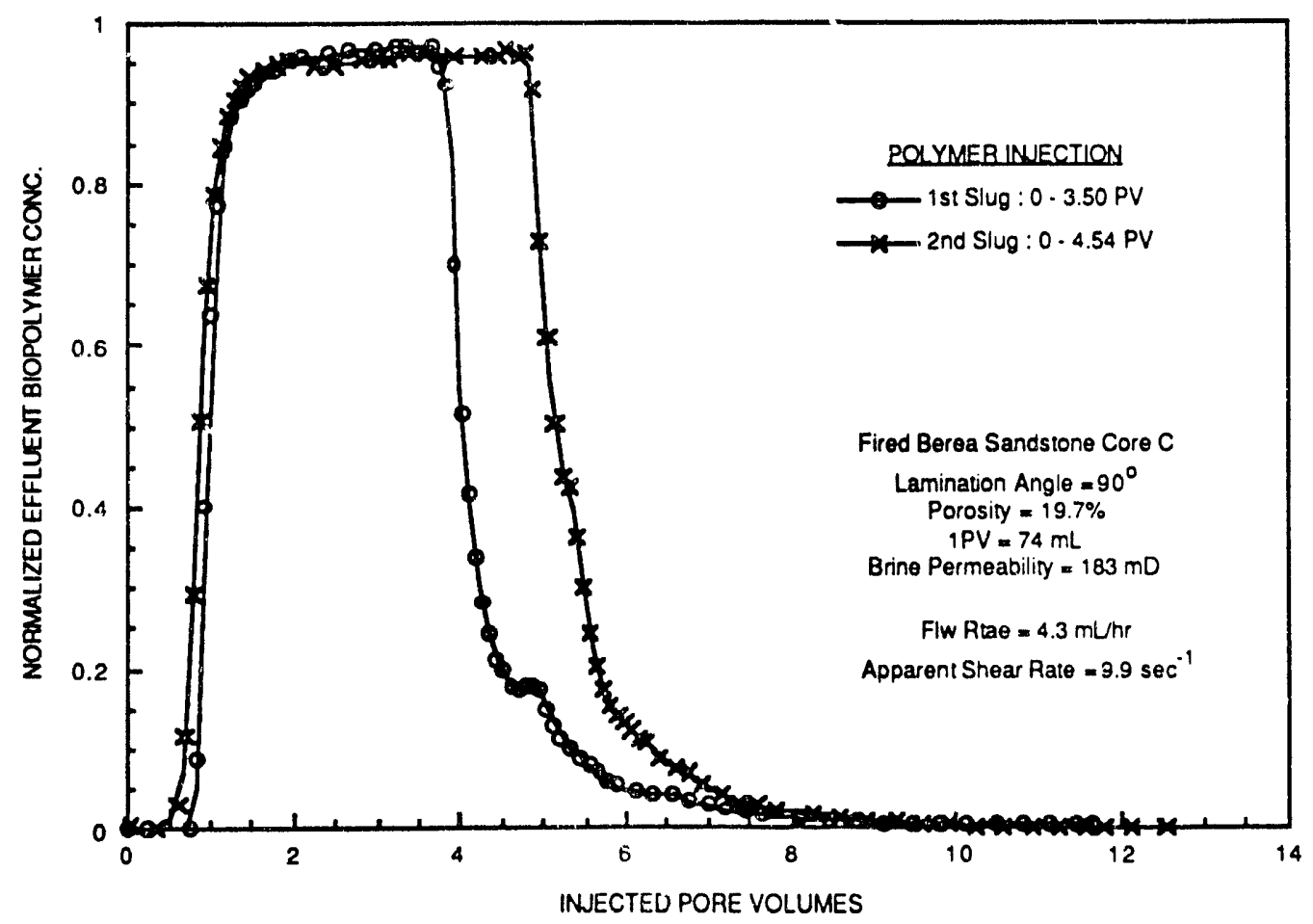

Figure 5. - Normalized effluent concentration profiles for biopolymer from core C. 


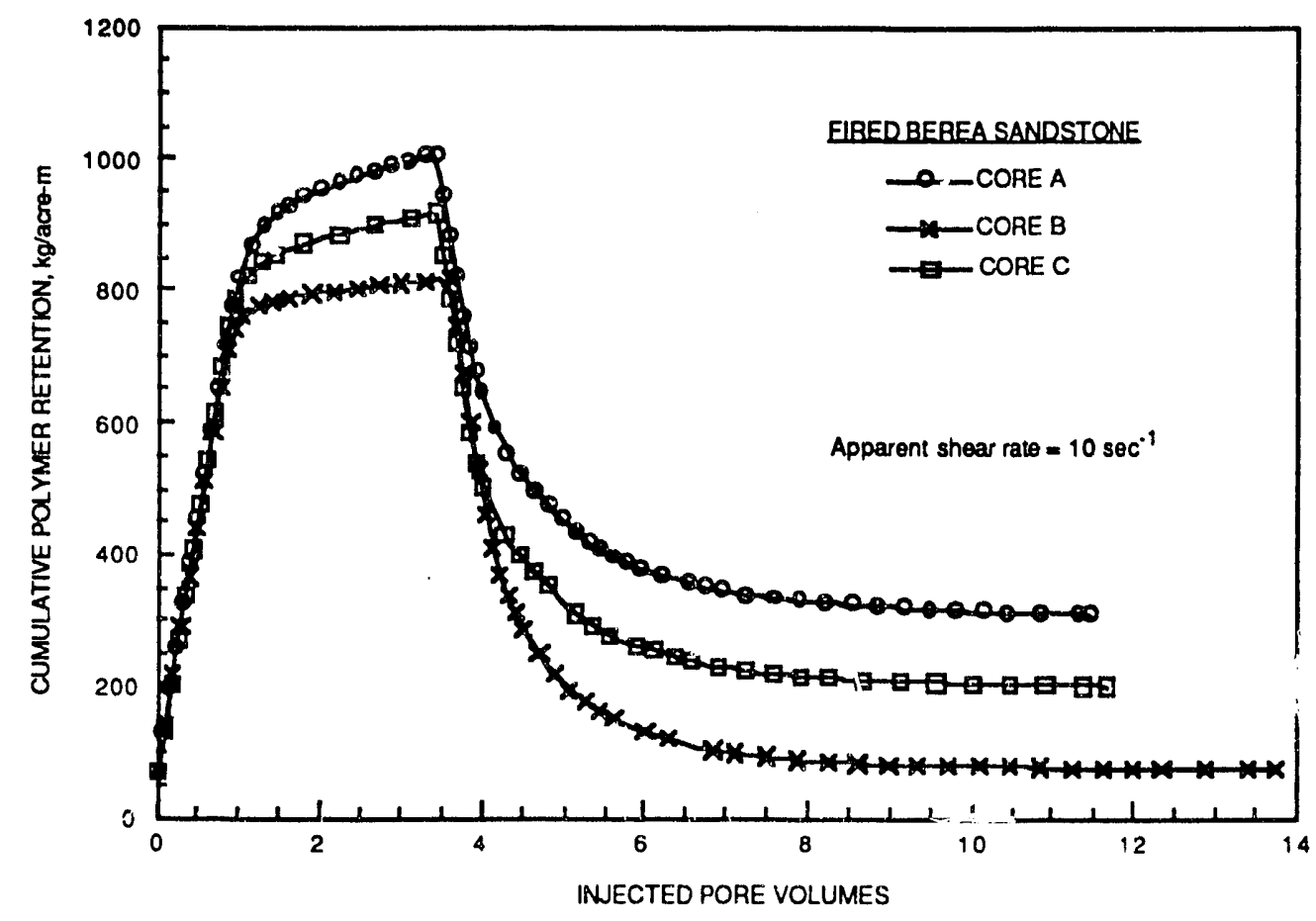

Figure 6. - Retention of biopolymer in cores A, B, and C during and after the first slug of polymer injection.

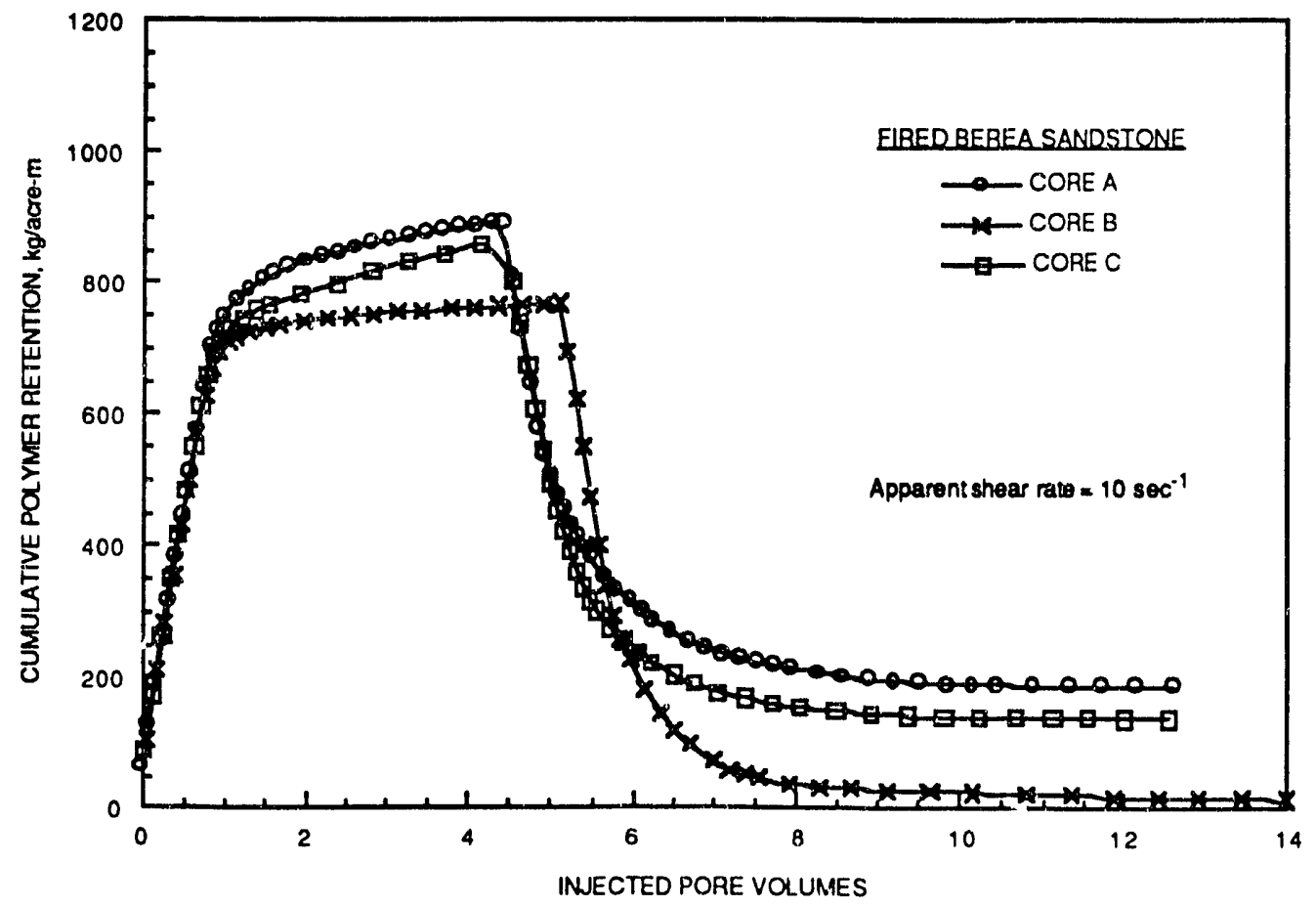

Figure 7. - Retention of biopolymer in cores A, B, and C during and after the second slug of 


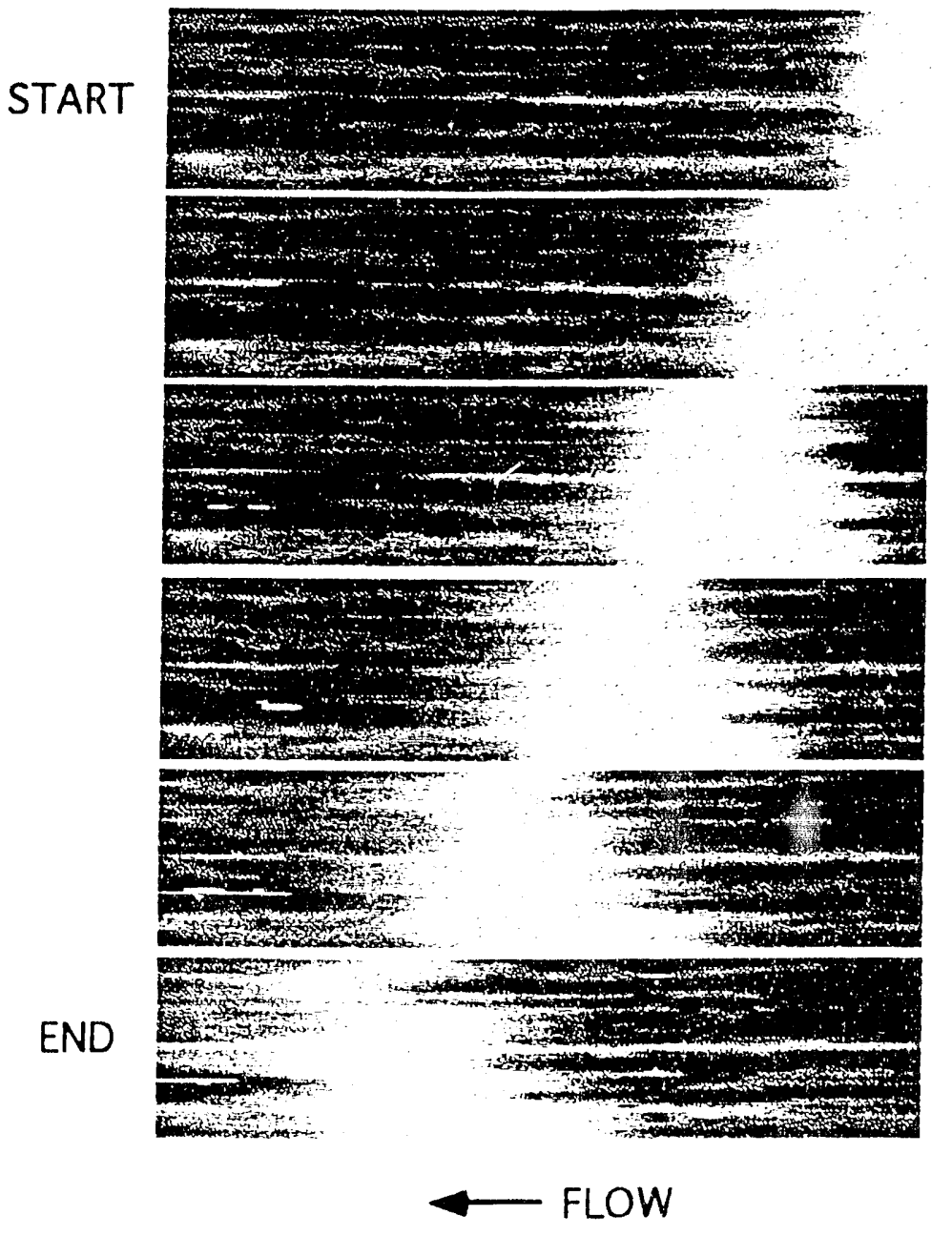

Before Polymer Injection

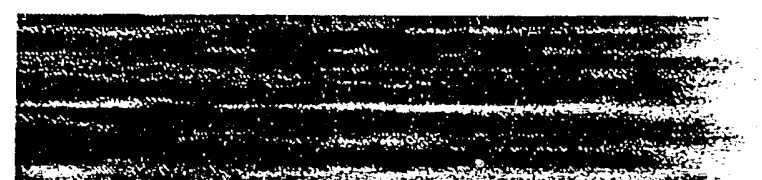

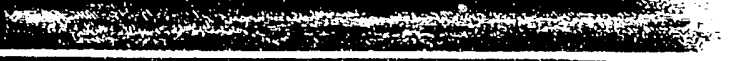
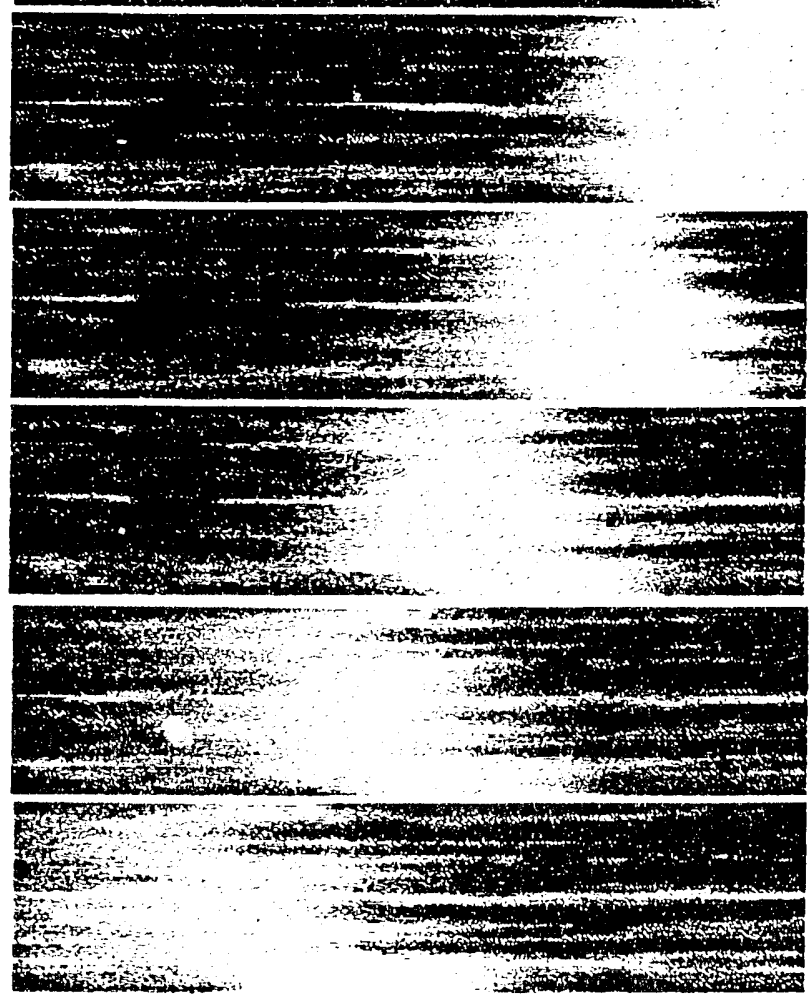

FLOW

After Polymer Injection

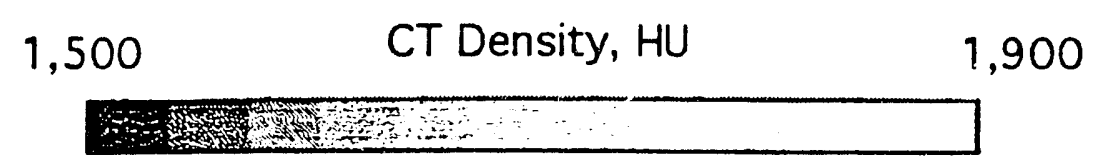

Figure 8. - CT images of tagged brine tracer slug (light color) in Berea core A saturated with untagged brine. 


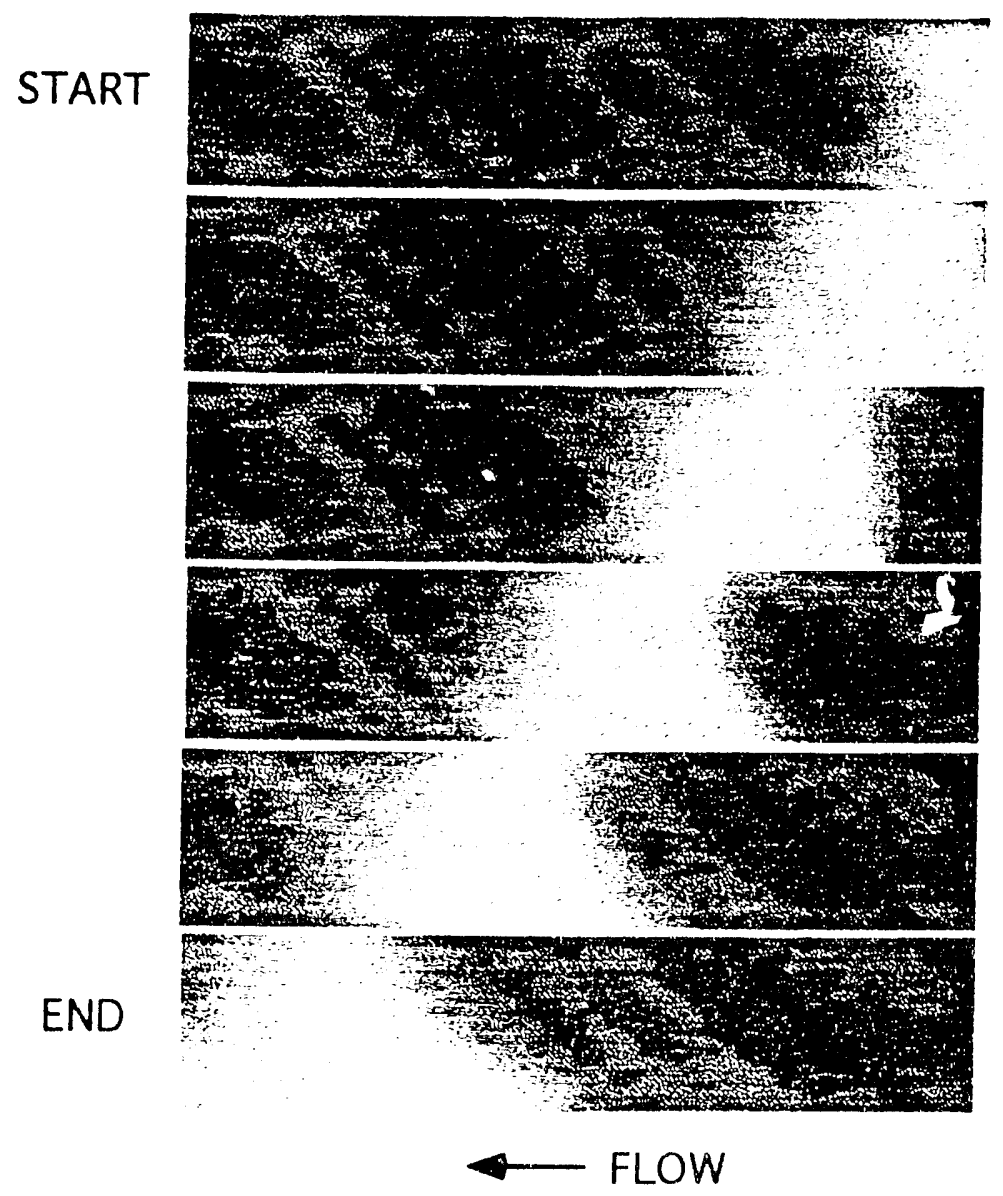

Before Polymer Injection
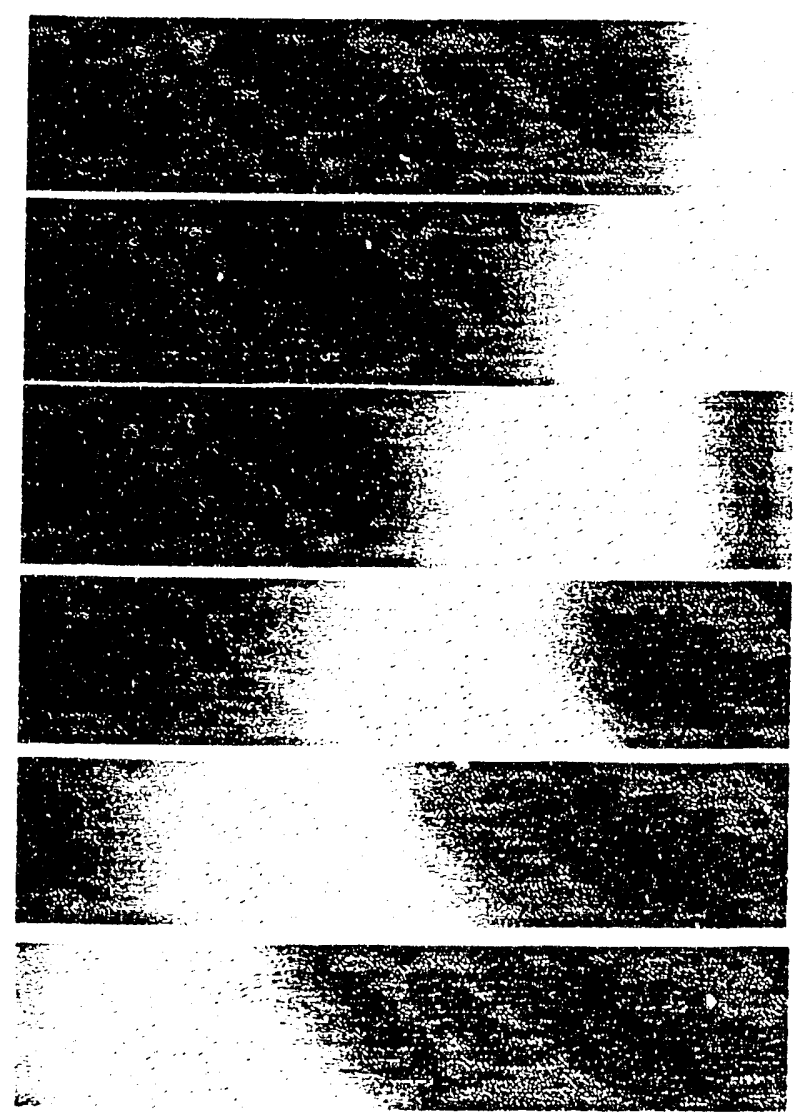

FLOW

After Polymer Injection

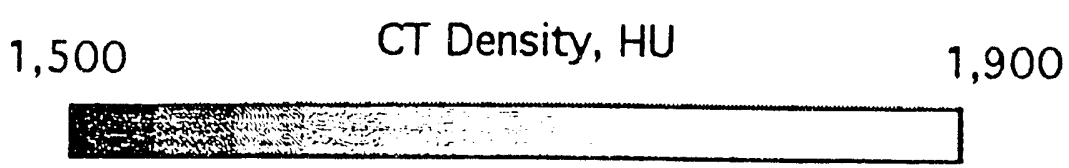

Figure 9. - CT images of tagged brine tracer slug (light color) in Berea core B saturated with untagged brine. 


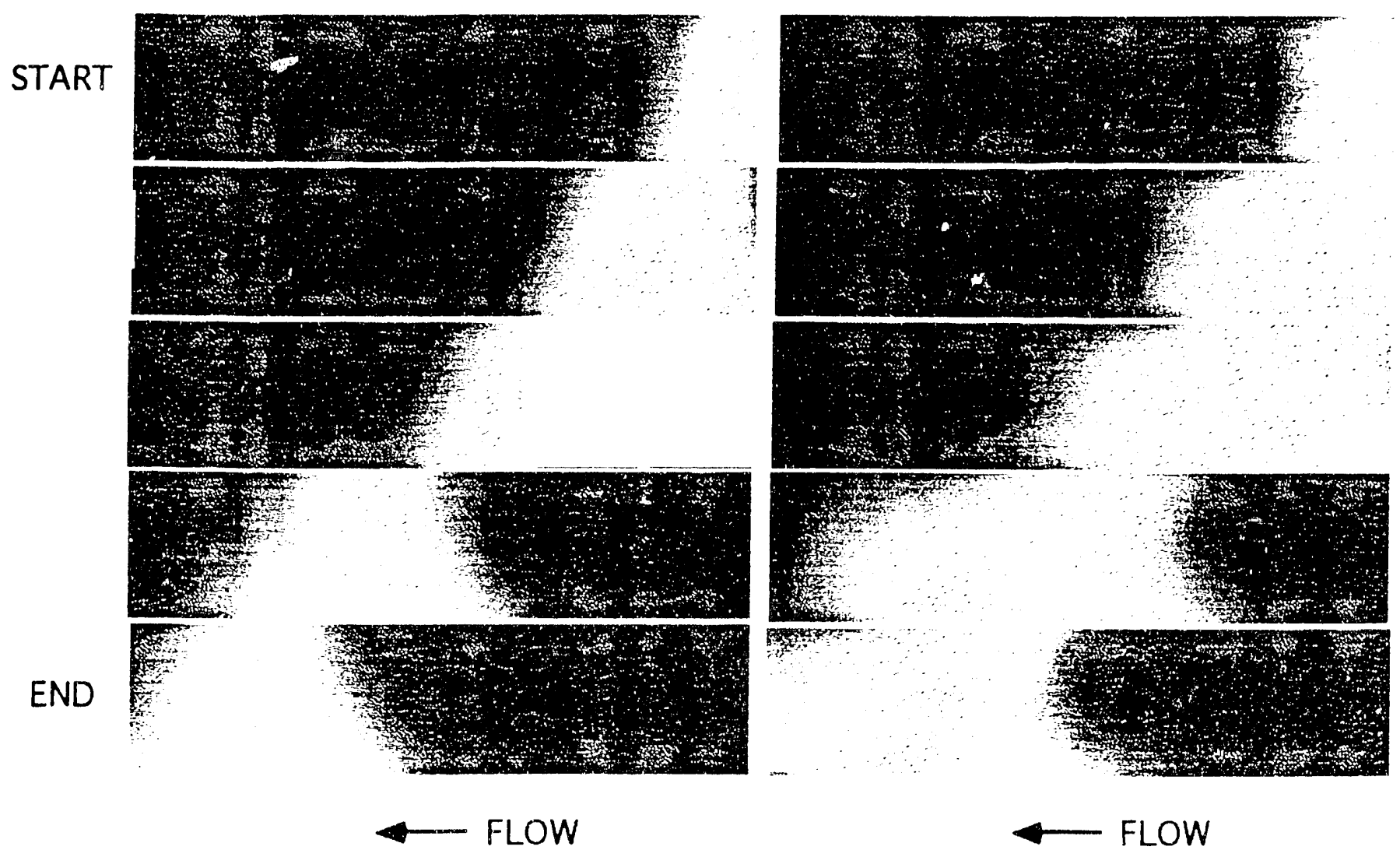

Before Polymer Injection After Polymer Injection

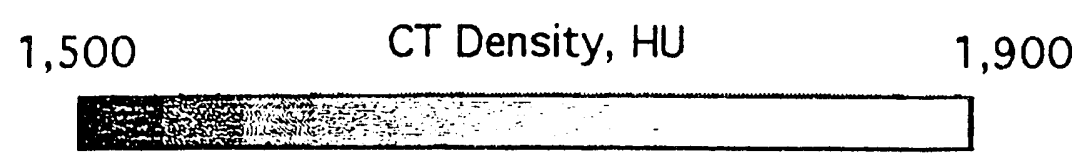

Figure 10. - CT images of tagged brine tracer slug (light color) in Berea core $\mathrm{C}$ saturated with untagged brine. 

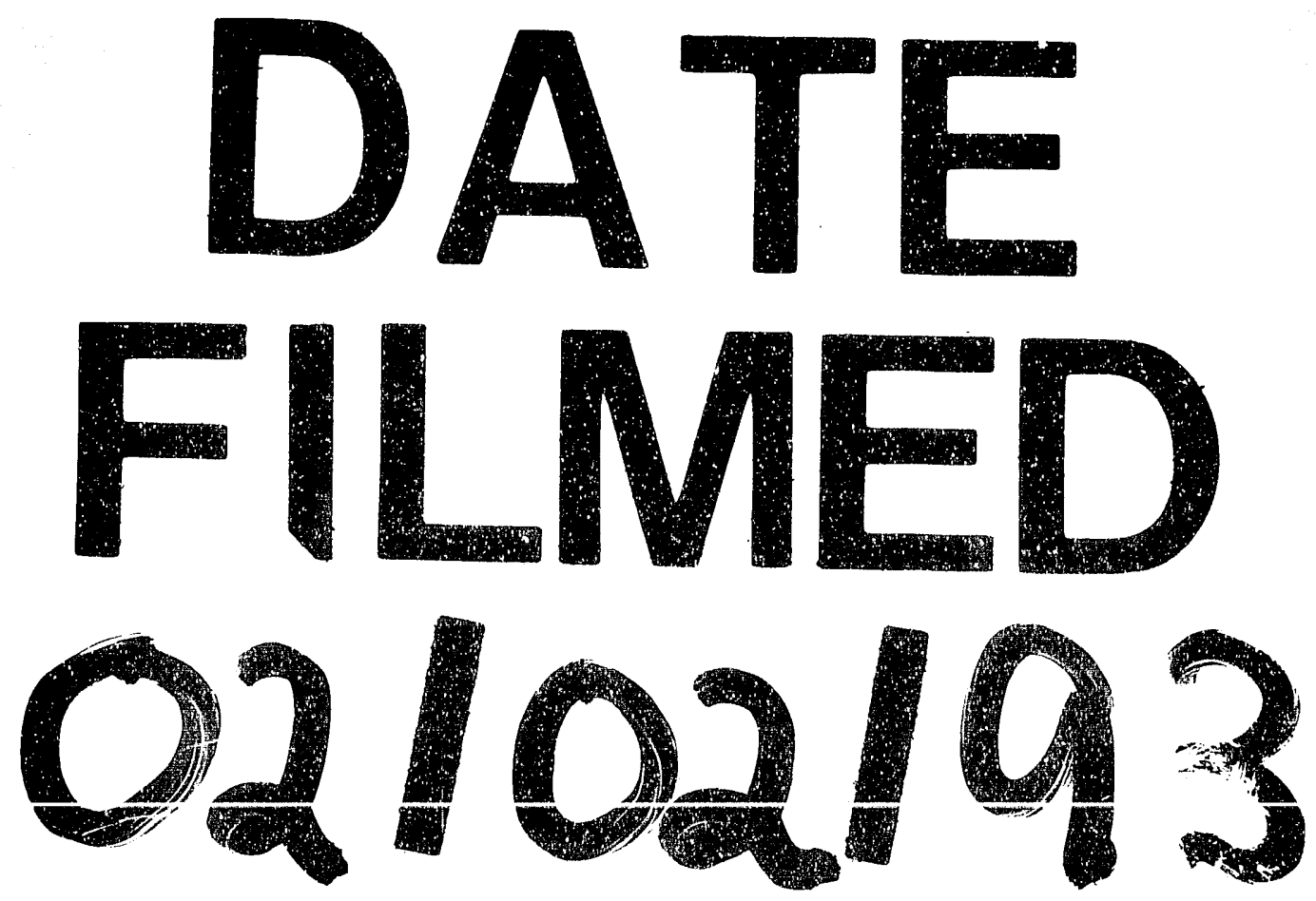
